\title{
Comparative anthelmintic efficacy of Arundo donax, Areca catechu, and Ferula assa-foetida against Haemonchus contortus
}

\author{
Eficácia anthelmíntica comparativa de Arundo donax, Areca catechu e Ferula \\ assa-foetida contra Haemonchus contortus
}

Syed Nadeem Badar'; Zafar Iqbal2; Muhammad Sohail Sajid2,3* (1); Hafiz Muhammad Rizwan ${ }^{4 *}$ (1); Muhammad Shareef5; Muhammad Abdullah Malik²; Muhammad Nisar Khan²

\author{
1 Department of Livestock and Dairy Development, Rawalpindi Division, Punjab, Pakistan \\ ${ }^{2}$ Department of Parasitology, University of Agriculture, Faisalabad, Pakistan \\ ${ }^{3}$ One Health Laboratory, Center for Advanced Studies in Agriculture and Food Security, University of Agriculture, Faisalabad, Pakistan \\ ${ }^{4}$ Section of Parasitology, Department of Pathobiology, KBCMA College of Veterinary and Animal Sciences, Narowal, subcampus UVAS \\ Lahore, Pakistan \\ ${ }^{5}$ Institute of Animal and Dairy Science, University of Agriculture, Faisalabad, Pakistan
}

How to cite: Badar SN, Iqbal Z, Sajid MS, Rizwan HM, Shareef M, Malik MA, et al. Comparative anthelmintic efficacy of Arundo donax, Areca catechu, and Ferula assa-foetida against Haemonchus contortus. Braz J Vet Parasitol 2021; 30(2): e001221. https://doi. org/10.1590/S1984-29612021028

\begin{abstract}
In the present study, anthelmintic activities of Arundo (A.) donax L., Areca (Ar.) catechu L., and Ferula (F.) assa-foetida $\mathrm{L}$. were determined. Leaves of $A$. donax L., latex of $F$. assa-foetida $\mathrm{L}$. and seeds of $A$. catechu $\mathrm{L}$. in different solvent fractions were subjected to in vitro (egg hatch assay; EHA, and adult motility assay; AMA) and in vivo (faecal egg count reduction test; FECRT) tests of anthelmintic activity using Haemonchus contortus model. In the AMA, crude aqueous methanol extracts (CAME) and ethyl acetate fractions of $F$. assa-foetida at $10 \mathrm{hr}$ post-treatment showed maximum mortality of $H$. contortus at $12.5-50 \mathrm{mg} \mathrm{mL}^{-1}$. In the EHA, CAME of $F$. assa-foetida was identified as a potent ovicide based on its low $\mathrm{LC}_{50}(16.9 \mu \mathrm{g} \mathrm{mL}-1)$, followed in order by Ar. catechu and $A$. donax. Results from the FECRT also showed the extract of $F$. assa-foetida L. to be more effective than those of Ar. catechu L. and $A$. donax L., against the gastrointestinal parasitic nematodes. Chloroform and ethyl acetate fractions showed better anthelmintic activities against the adult worms in vitro, while CAME of these plants were better than their crude powders in vivo. It is recommended to document and investigate indigenous knowledge of possible medicinal plants to plan scientific trials that may justify their endorsement.
\end{abstract}

Keywords: Arundo donax L., Areca catechu L., Ferula assa-foetida L., Haemonchus contortus, in vivo, in vitro.

\begin{abstract}
Resumo
No presente estudo, as atividades anti-helmínticas de Arundo (A.) donax L., Areca (Ar.) Catechu L. e Ferula (F.) assafoetida L. foram determinadas. Folhas de A. donax L., látex de F. assa-foetida L. e sementes de Ar. catechu L. em diferentes frações de solvente foram submetidos a testes in vitro (teste de eclosão de ovos, EHA e ensaio de motilidade em adultos, AMA); e in vivo (teste de redução da contagem de ovos fecais, FECRT) de atividade antihelmíntica, usando-se Haemonchus contortus. Na AMA, extratos aquosos brutos de metanol (CAME) e frações de acetato de etila de F. assa-foetida. Dez horas pós-tratamento, apresentaram mortalidade máxima de $H$. contortus em 12,5-50 mg mL-1. No EHA, CAME de F. assa-foetida foi identificado como um ovicida potente baseado em seu baixo LC50 (16,9 $\left.\mu \mathrm{g} \mathrm{mL}^{-1}\right)$, seguido em ordem por Ar. catechu e A. donax. Os resultados do FECRT também mostraram que o extrato de F. assa-foetida L. é mais eficaz do que o de Ar. catechu L. e A. donax L., contra nematoides parasitas gastrointestinais. As frações clorofórmio e acetato de etila mostraram melhores atividades anti-helmínticas contra vermes adultos in vitro, enquanto o CAME dessas plantas foi melhor do que o pó bruto in vivo. Recomenda-se documentar e investigar o conhecimento indígena de possíveis plantas medicinais para planejar ensaios científicos que possam justificar seu endosso.
\end{abstract}

Palavras-chave: Arundo donax L., Areca catechu L., Ferula assa-foetida L., Haemonchus contortus, in vivo, in vitro.

Received January 18, 2021. Accepted March 10, 2021

*Corresponding author: Muhammad Sohail Sajid. E-mail: drsohailuaf@hotmail.com. Hafiz Muhammad Rizwan. E-mail: hm.rizwan@uvas.edu.pk 


\section{Introduction}

Production of the livestock depends upon regular supplies of food, healthcare and proper husbandry practices. Changes in the climate and other factors affect the prevalence of parasitic infections and consequently the productivity, longevity, fertility, and survivorship of the livestock (Thornton et al., 2009). In small-holder dairy farming systems, gastrointestinal (GI) parasites are among the major threats to animal health and welfare and have high economic significance, especially in the resource-poor countries like Pakistan (Iqbal et al., 2007, Rizwan et al., 2017, 2019; Ahmad et al., 2020). Lack of proper awareness, underfeeding, abundant vector populations, and availability of a wide variety of hosts provide the best opportunity for the transmission of parasitic helminths (Zvinorova et al., 2016).

Although most veterinarians and farmers use anthelmintic drugs for the control of helminths as a cornerstone in the small-holder dairy farming systems in the resource-poor countries like Pakistan (Akhter et al., 2014, Khan et al., 2017), the development of widespread anthelmintic resistance (Jabbar et al., 2006), and concerns about toxicity and residues in products (Gasbarre et al., 2001) have led to the revival of awareness about the potential importance of traditional veterinary practices and the need to validate their utility (Ketzis et al., 2002, Rizwan et al., 2019). Ethnoveterinary medicine (EVM) can contribute to sustainable practices in the modern world, especially in developing countries (Confessor et al., 2009). Clinically useful efficacy, greater accessibility, and lower costs are the major benefits associated with EVM (Mwale et al., 2005; Badar et al., 2017; Qudoos et al., 2017). Consequently, surveys about documentation and scientific studies on the validation of the use of plants against parasitic infections have been conducted around the world (Bizimenyera et al., 2006; McGaw et al., 2007; Kareparamban et al., 2012; Faruque et al., 2018).

The in vitro and in vivo anthelmintic efficacy of crude aqueous-methanol extracts (CAME) of Arundo (A.) donax and its various fractions (petroleum spirit, chloroform, and ethyle acetate) were reported against Haemonchus (H.) contortus (Sharatkumar et al., 2004; Al-Snafi, 2015). Miles et al. (1993) reported anthelmintic efficacy of $A$. donax extracts against Oesophagostomum sp. Ascaris sp., and Paramphistomum sp. of cattle. The anthelmintic efficacy of an ethanolic extract of Ferula (F.) assa-foetida against Fasciola gigantica was reported by Kumar \& Singh (2014). An ethanolic extract of Areca (Ar.) catechu significantly inhibited fumarate reductase and succinate dehydrogenase activities in Cotylophoron cotylophorum (Dhanraj \& Veerakumari, 2016). The data regarding scientific evaluation of A. donax against $H$. contortus models is available; however, we did not find in vitro and in vivo scientific evaluation of $F$. assa-foetida L. and Ar. catechu extracts against $H$. contortus models.

In Pakistan, information related to medicinal plants used for the treatment of parasitic infections and other illnesses transfers from one generation to another. However, this indigenous knowledge varies greatly in different ethnic groups and from region to region due to local variation in the availability of plants (Hussain et al., 2008). Due to geographic and climatic diversity in Pakistan, a wide variety of medicinal plants has been reported from different parts of the country (Iqbal et al., 2004; Muhammad et al., 2005; Hussain et al., 2008; Goraya et al., 2013; Badar et al., 2017). Most of these plants are used by native healers without specific knowledge about the active ingredients. It is important to document and validate plants used by local communities for medicinal purposes before their disappearance due to environmental and technological changes (Goraya et al., 2013; Badar et al., 2017). In connection with earlier studies, the objective of this work was to determine the anthelmintic activities of the leaves of $A$. donax L., latex of F. assa-foetida L. and seeds of Ar. catechu $\mathrm{L}$ through in vitro and in vivo assays against $H$. contortus models.

\section{Materials and Methods}

\section{Collection of plant materials}

The plants A. donax L., Ar. catechu L. and F. assa-foetida L were selected during a documentation survey of the herbs used for the treatment of helminthiasis in animals (Badar et al., 2017). Briefly, participatory epidemiological procedures were adopted to involve the local healers as respondents for the identification of the most commonly used plants for the treatment of worm infection in animals of the area (Hussain et al., 2008). The leaves of $A$. donax L. (voucher No. Jg8/2006), latex of F. assa-foetida L. (voucher No. Jg24/2006), and seeds of Ar. catechu L. (voucher No. Jg7/2006) were collected from the market and field of district Jhang, Punjab, Pakistan. Identification 
of the plants was done by Prof. Dr. Abdul Wahid from the Department of Botany, University of Agriculture, Faisalabad, Pakistan.

\section{Extraction and fractionation}

\section{Extraction}

The leaves of $A$. donax L., latex of $F$. assa-foetida $\mathrm{L}$. and seeds of $A r$. catechu $\mathrm{L}$. were dried at the room temperature. The dried specimens were ground to powder with an electric grinder. The powder was soaked for 3 days in an aqueous-methanol 30:70 suspension for the preparation of crude aqueous-methanol extracts (CAME) and filtered through muslin cloth and filter paper. The whole procedure was repeated thrice and then by the use of rotary evaporator at $40^{\circ} \mathrm{C}$ and low pressure, the combined filtrate was evaporated to get CAME (Tabassam et al., 2008).

\section{Fractionation}

Organic solvents, including ethyl acetate, chloroform, and petroleum spirit, were used to fractionate the crude extracts as described (Williamson et al., 1998). Briefly, after dissolving crude extract (20 g) in the distilled water $(20 \mathrm{~mL})$, and petroleum spirit $(60 \mathrm{~mL})$ in a funnel, was shaken vigorously. To separate the layers of petroleum spirit and the distilled water, the funnel was kept undisturbed for about $30 \mathrm{~min}$. Another $60 \mathrm{~mL}$ petroleum spirit was added and the procedure was repeated until a clear petroleum spirit layer was obtained. All separated petroleum spirit layers were pooled and evaporated in a rotary evaporator. Fractions of chloroform and ethyl acetate were obtained by adopting the same procedure.

\section{Parasitological procedures}

\section{Procurement of adult Haemonchus contortus}

Following the methods of Alawa et al. (2003), adult Haemonchus (H.) contortus worms were obtained from the abomasal contents of slaughtered sheep. Each abomasum was separated from the small intestine and shifted to the Ethnoveterinary Research Center at the Department of Parasitology, University of Agriculture, Faisalabad, Pakistan and examined within $3 \mathrm{~h}$ of slaughter. The abomasum was split open and their contents washed gently with water in separate buckets and collected. The abomasum was divided longitudinally and the whole mucosa was examined carefully. The worms were collected gently from the infected abomasum with the help of forceps. Some of the worms were separated to use in adult motility assay; whereas, from the remaining worms, females were separated and crushed using a pestle and mortar to liberate the eggs to be used in egg hatch assays.

\section{Adult Motility Assay (AMA)}

CAME and fractions of chloroform, ethyl acetate and petroleum spirit at concentrations of 50, 25, 12.5, 6.25, 3.12 and $1.56 \mathrm{mg} \mathrm{mL}^{-1}$ in phosphate-buffered saline (PBS) along with levamisole $\left(0.55 \mathrm{mg} \mathrm{mL}^{-1}\right.$; positive control) and PBS (negative control) were prepared. Adult live Haemonchus contortus were collected from abomasa of sheep procured from the local slaughter house. Minimum 10 worms were separated into individual Petri dishes and exposed to the above treatments. Each treatment was repeated thrice at the room temperature and the number of surviving and dead worms was observed at $0,2,4,6,8,10,12$, and 24 hours post-treatment as described elsewhere (Lateef et al., 2003; Zaman et al., 2012).

\section{Egg Hatch Assay (EHA)}

Eggs were separated from female $H$. contortus by triturating them in a pestle and mortar. About 250 eggs in $1.5 \mathrm{~mL}$ water were placed in each well of a 24-well plate. The CAME and fractions of chloroform, ethyl acetate and petroleum spirit along with albendazole (positive control) and PBS (negative control) were used at 1.2, 12, 120,1200 and $12000 \mu \mathrm{g} \mathrm{m}^{-1}$. The plate was incubated at $28^{\circ} \mathrm{C}$ for $36 \mathrm{hr}$. After incubation, eggs and larvae (dead or alive) were counted using an inverted microscope (Coles et al., 1992; Zaman et al., 2012). Each treatment was repeated in triplicate. 


\section{Faecal Egg Count Reduction Test (FECRT)}

Naturally H. contortus- infected sheep (4-8 months-old) were selected for FECRT. The study was conducted at a local farm of Faisalabad district, Punjab, Pakistan. Animals were screened through the "Modified McMaster test". This study was approved by Research Ethics Committee, Faculty of Veterinary Science, University of Agriculture, Faisalabad, Pakistan. Standard guidelines for the institutional animal care and use (IACU), University of Agriculture, Faisalabad, Pakistan were followed. Sheep were divided into 20 groups of 5 animals each through a complete randomized design. Groups 1 and 2 were treated with PBS (negative control) and levamisole (positive control) at $7.5 \mathrm{mg} \mathrm{kg}^{-1}$ body weight, respectively. Groups 3-5 were treated with the crude powder (CP) of $A$. donax at 1, 4, and $7 \mathrm{~g} \mathrm{~kg}^{-1}$ body weight and groups 6-8 were treated with the CAME of $A$. donax at $1 \mathrm{~g}, 4 \mathrm{~g}, 7 \mathrm{~g} \mathrm{~kg}^{-1}$ body weight, respectively. Groups 9-11 were treated with the CP of $F$. assa-foetida at $0.33,0.66$, and $1 \mathrm{~g} \mathrm{~kg}^{-1}$ body weight, respectively and groups 12-14 were treated with the CAME of $F$. assa-foetida at $0.33,0.66$, and $1 \mathrm{~g} \mathrm{~kg}^{-1}$ body weight, respectively. Similarly, groups 15-17 were treated with the CP of Ar. catechu at $0.33,0.66$, and $1 \mathrm{~g} \mathrm{~kg}^{-1}$ body weight, respectively, and groups 18-20 were treated with the CAME of Ar. catechu at $0.33,0.66$, and $1 \mathrm{~g} \mathrm{~kg}^{-1}$ body weight, respectively. Each treatment was given once per os and faecal egg counts were done on days $0,4,8$, and 12 post-treatment.

\section{Statistical analyses}

A characteristic sigmoid dose-response curve was transformed into a linear function (to get a constant or fixed rate of hatching with the increase concentration of different fractions) via the probit transformation of the egg hatch test (EHT) data. Probit analysis was used to calculate the lethal concentration $50\left(\mathrm{LC}_{50}\right)$ of each extract for the EHT (Hubert \& Kerboeuf, 1992). The Regression analysis was used to determine the effect of independent variables(concentration level) on the dependent variable (hatching) as described by Zaman et al. (2012). The adult motility assay (AMA) data were analyzed by the Duncan's multiple range (DMR) test to compare means of the number of dead worms. For FECRT, the results were expressed as eggs per gram (Mean \pm SEM) of faeces and means were compared by using DMR Test. All statistical analyses were carried out using SAS software (SAS, 1998).

\section{Results}

\section{In vitro anthelmintic activity}

In the AMA, $100 \%$ mortality (at $10^{\text {th }}$ hr post-exposure) of $H$. contortus was noted with the CAME and ethyl acetate fractions of $F$. assa-foetida at $12.5-50 \mathrm{mg} \mathrm{mL}^{-1}$. The ethyl acetate fraction of $A$. donax showed maximum efficacy, followed in order by the fractions of chloroform, CAME and petroleum spirit. Among different fractions of Ar. Catechu, CAME showed the maximum mortality, followed in order by the fractions of ethyl acetate, chloroform and petroleum spirit. Levamisole caused $100 \%$ worm mortality within $2 \mathrm{hr}$ post-exposure. The results of the AMA for the various treatments were observed as given in Table 1.

In the EHA, the CAME of $F$. assa-foetida showed the maximum ovicidal activity $\left(\mathrm{LC}_{50}=16.9 \mu \mathrm{g} \mathrm{mL}-1\right)$, followed in order by those of Ar. catechu and $A$. donax. The chloroform fractions of $F$. assa-foetida and $A$. donax showed more ovicidal activity than that of Ar. catechu. Both the regression values and their correlations regarding the effects of the treatments on egg hatching indicated that a better concentration-dependent effect was found with the CAME of $F$. assa-foetida compared to those of Ar. catechu and A. donax. The concentration-dependent effects of petroleum spirit fractions were observed as given in Figure 1.

\section{In vivo anthelmintic activity}

Both the crude powder (CP) and crude aqueous methanol extracts (CAME) of the tested plants showed dosedependent, variable levels of anthelmintic activity (Table 2). The anthelmintic efficacy of the CP of the plants ranged from $5.4 \%$ to $50.5 \%$. The highest reduction (50.5\%) in faecal egg count was recorded for $A$. donax at $7 \mathrm{~g} \mathrm{~kg}^{-1}$ than for $F$. assa-foetida at $1 \mathrm{~g} \mathrm{~kg}^{-1}$. The anthelmintic efficacies of the CAME preparations were not consistent with those recorded for the CP. The effects of all plant treatments (12 days post-treatment) were statistically different from untreated controls $(P<0.05)$. Differences in eggs per gram $(E P G)$ values of the levamisole-treated group from those of plant extract-treated groups were statistically significant $(P<0.05)$. However, differences in EPG values of the groups treated with different doses of the plant extracts were not statistically significant $(P>0.05)$ on days 8 and 12 post-treatment, treated with CP of F. assa-foetida and Ar. catechu. 


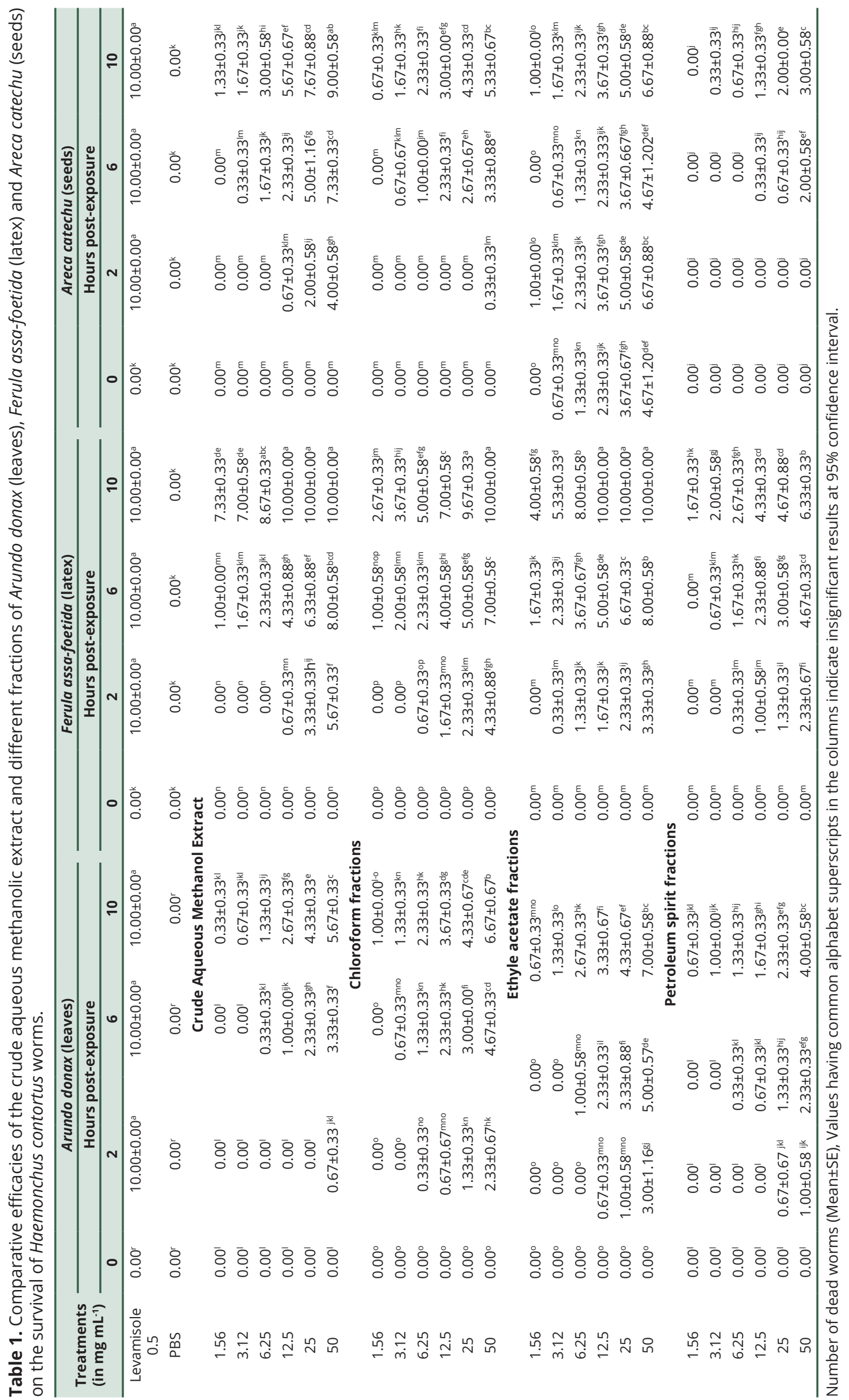




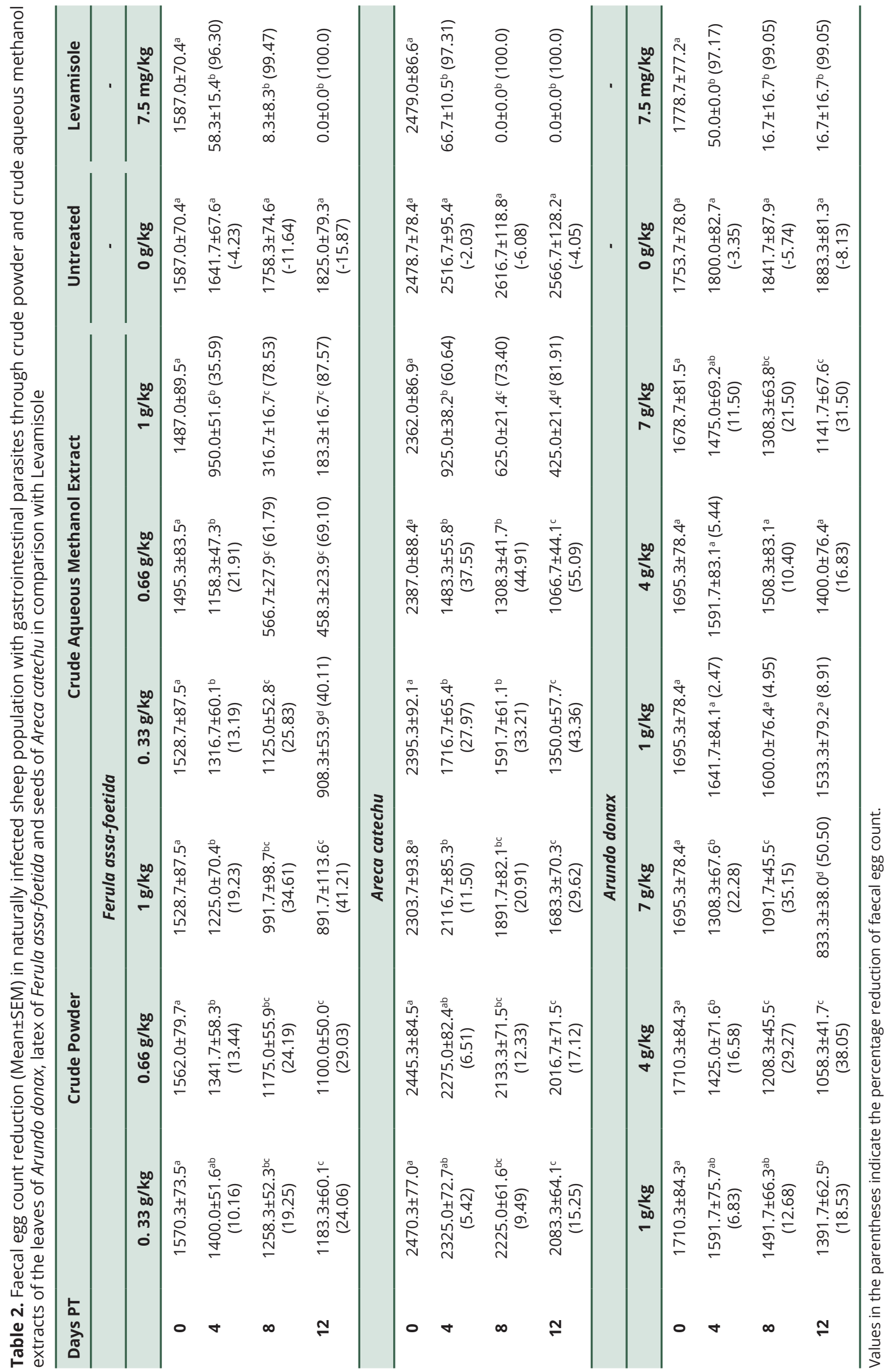



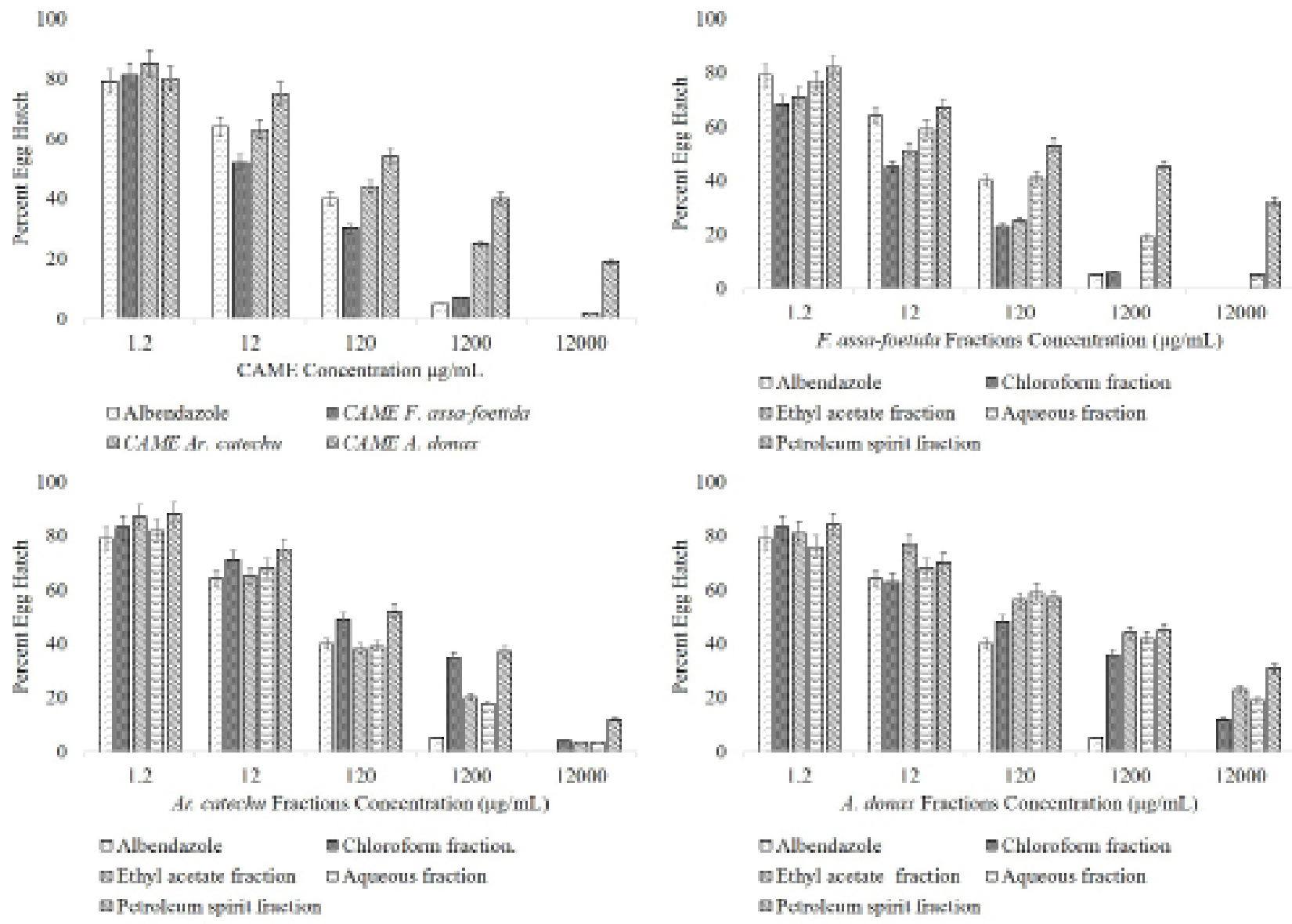

Figure 1. In vitro hatching (\%) of Haemonchus contortus eggs through crude aqueous methanol extract (CAME) and fractions of Ferula (F.) assa-foetida, Areca (Ar.) catechu and Arundo (A.) donax.

\section{Discussion}

Parasitic infection is a key problem responsible for reduction in the productivity of animals, partly due to poor feed utilization (Pedreira et al., 2006). H. contortus is one of the principal parasitic nematodes of small ruminants, and the cause of huge economic losses (Radostits et al., 2000). The control of haemonchosis and other parasites relies mainly on the use of anthelmintics (Khan et al., 2017). The efficacy of these chemicals is threatened by the development and spread of resistance. However, success in the development of new drugs for parasitic infections is limited (Kaminsky et al., 2008; Kumarasingha et al., 2016). Searching for new, safe, and effective anthelmintic compounds from plants is a promising way to control parasitic infection (Waller et al., 2001; Kumarasingha et al., 2016). Nature has provided a variety of medicinal plants, e.g., Trachyspermum ammi (L.) Sprague, Punica granatum L., Nicotiana tabacum L., Artemisia brevifolia, Allium sativum, Ferula asafoetida, Syzygium aromaticum and Withania coagulans Dunal, to cure parasitic diseases. The chemical compounds present in these plants have different solubilities in various solvents (Iqbal et al., 2004; Kumar \& Singh, 2014; Atma et al., 2017). Different solvents can dissolve different chemical compounds (solutes) that underlie biological activities (lqbal et al., 2007; McGaw et al., 2007; Altemimi et al., 2017). Such studies will help to identify potential candidates for alternative control through plant-based, novel anthelmintics. In the present study, solvents were used to fractionate plant extracts in order to identify those with the highest activity against the $H$. contortus model.

Various fractions of $F$. assa-foetida have been isolated, including gum, resins, volatile oils, coumarin derivatives and various monoterpenes, ferulic acid, farnesiferoles, disulfides, symmetric trisulfides and tetrasulfides (Hofer et al., 1984; Kajimoto et al., 1989; Kapoor, 1990). The resin of $F$. assa-foetida has various properties, such as anticoagulant, smooth muscle relaxant, anti-diabetic, anticarcinogenic, antioxidant, antispasmodic, antihepatotoxic, antiulcerogenic, anticholesterolemic, anti-inflammatory, antifertility, antifungal, antiparasitic and anthelmintic (Kareparamban et al., 2012, Amalraj \& Gopi, 2016). The gum extract of F. assa-foetida has been used to cure diarrhea, constipation, abdominal pain, and parasitic infections (Fernch, 1971). Inhibition of the growth of Shigella sonnei and 
Staphylococcus aureus has also been reported by the gum extract of $F$. assa-foetida (Kapoor, 1990). Gundamaraju (2013) reported significant anthelmintic activity of $F$. assa-foetida at a concentration of $100 \mathrm{mg} \mathrm{mL}^{-1}$. Paralysis, as well as lethality, of an aqueous extract of $F$. assa-foetida was comparable to piperazine citrate at a concentration of $100 \mathrm{mg} \mathrm{mL}^{-1}$. Polyphenolic compounds and flavonoids are the main phytochemical components of crude extracts. Polyphenolic compounds such as tannins have been documented as anthelmintics (Bate-Smith, 1962; Iqbal et al., 2007). Kumar \& Singh (2014) reported the $L C_{50}$ of an ethanolic extract of the dried-root latex powder of $F$. assa-foetida (4.88 $\left.\mathrm{mg} \mathrm{mL}^{-1}\right)$ followed in order by the dried clove powder of $A$. sativum (3.48 $\left.\mathrm{mg} \mathrm{mL}^{-1}\right)$, and dried flower bud powder of Syzygium aromaticum $\left(2.95 \mathrm{mg} \mathrm{mL}^{-1}\right)$ against Fasciola gigantica. The possible anthelmintic effects of $F$. assa-foetida may be due to interference with energy generation in parasites by uncoupling oxidative phosphorylation or due to presence of tannins in the extracts that can bind to glycoprotein on the cuticle of the parasite and cause death (Mali \& Wadekar, 2008).

Areca catechu nuts were used as anthelmintics and appear in the British pharmacopoeia for the treatment of parasitic infections (Raghavan \& Baruah, 1958). The nuts of Ar. catechu contain tannins, gallic acid, oil gum, volatile oils, lignins (Huang, 1992), alkaloids, phenolic compounds, beta-sitosterol, catechins, amino acids and various saline substances (Duke, 1992; Wang et al., 1997; Chu, 2001). An ethanolic extract of Ar. catechu significantly inhibited fumarate reductase and succinate dehydrogenase activities in Cotylophoron cotylophorum (Dhanraj \& Veerakumari, 2016). The combined efficacy of Ar. catechu and Anredera (An.) cordifolia showed significant elimination of Ascaridia galli (60\%) in chickens and reduced EPG of faeces. However, in a group treated with alkaloids and saponins contained in Ar. catechu and An. cordifolia showed antagonistic activity (Prastowo et al., 2017). Baby \& Raphael (2014) reported dose-dependent anthelmintic activity of ethanolic extract of Ar. catechu root against Pheretima posthuma. The results of the study conducted by Yamson et al. (2019) revealed that there was no movement of Fasciola sp. when exposed to $40 \%$ ethanol extract Ar. catechu. Most of the pharmacological and biological effects, such as inhibition of acetylcholinesterase, stimulation of the relaxed bowel and cholinomimetic effects of Ar. catechu, are due to the condensed tannins (Kapoor, 1990; Amudhan et al., 2012). Direct and/or indirect pharmacological effects of the condensed tannins on the GI parasites have been reported (i.e., Butter et al., 2000; Molan et al., 2000; Iqbal et al., 2007; Naumann et al., 2017). Condensed tannins can interfere with physiological functioning of parasites, development of infective larval stages and hatching of parasite eggs (Molan et al., 2000).

In Ayurvedic medicine, a decoction of $A$. donax was used as haemostatic, in toothache, as a diuretic and as an emollient (Passalacqua et al., 2007). It is also used to diminish the secretion of milk and to stimulate menstrual discharge (Chopra et al., 1956). It is a potential biomass plant with an invasive potential in riparian areas (Nackley \& Kim, 2015; Al-Snafi, 2015) and is also used for phytoremediation in Ni-contaminated soils (Atma et al., 2017). Five indole-3-alkylamine bases (5-methoxy- $\mathrm{N}$-methyl-tryptamine, bufotenidine, bufotenine, $\mathrm{N}$-dimethyltryptamine, and dehydrobufotenine) have been isolated from rhizomes of $A$. donax (Ghosal et al., 1969). Antispasmodic and hypotensive effects against serotonin, acetylcholine, and histamine-induced spasms by a defatted, ethanolic extract of $A$. donax rhizomes have been reported (Al-Snafi, 2018). In a study conducted by Sharatkumar et al. (2004), 25-50 mg mL-1 A. donax showed significant anthelmintic effects. The highest mortality of $H$. contortus after levamisole (used as a reference drug) was $56.7 \%$, with the CAME of $A$. donax at the concentration of $50 \mathrm{mg} \mathrm{mL}^{-1}$ at $10 \mathrm{hr}$ post-exposure. Among various fractions of $A$. donax against $H$. contortus, ethyl acetate was the most active, followed in order by chloroform, aqueous and petroleum spirits extracts. In a FECRT, 50.5\% reduction of eggs was recorded by the CP of $A$. donax in naturally infected sheep. However, $A$. donax exhibited ovicidal activity, with $\mathrm{LC}_{50}$ of $200.1 \mu \mathrm{g} \mathrm{mL}-1$. Around $55 \%$ efficacy of $A$. donax extracts was recorded against various $\mathrm{Gl}$ parasites of cattle (Miles et al., 1993).

In conclusions, the preparations of $F$. assa-foetida were toxic to $H$. contortus in vitro. In the AMA and EHA, CAME showed maximum mortality and ovicidal activity. However, the ethyl acetate fraction of $A$. donax showed maximum efficacy against adult worms, while chloroform fractions of $F$. assa-foetida and $A$. donax showed maximum ovicidal activity. In vivo efficacy of CP and CAME in this study ranged from $5.4 \%$ to $50.5 \%$. The higher reduction (50.5\%) in faecal egg count was recorded for $A$. donax at the dose rate of $7 \mathrm{~g} \mathrm{~kg}^{-1}$. Differences in the values of EPG between the levamisole-treated group and those treated with plant extracts were statistically significant $(\mathrm{P}<0.05)$.

\section{Acknowledgements}

The study was partially-funded by the project titled "Documentation and evaluation of some traditionally used ethnobotanicals for their anthelmintic activity" No. 20-362/R\&D/05, The Higher Education Commission, Islamabad, 
Pakistan. The authors thank the local farming community and personnel of the Livestock and Dairy Development Department of the selected sites for providing valuable information about commonly used plants against gastrointestinal parasitism and assistance in collection of the plants. Identification of the plants was done by Prof. Dr. Abdul Wahid from the Department of Botany, University of Agriculture, Faisalabad, Pakistan. Authors are very thankful to Emeritus Professor Dr. Timothy G. Geary, McGill University, McDonald Campus, Quebec, Canada, for English language revision of the manuscript.

\section{References}

Ahmad S, Sajid MS, Khan MK, Nadeem R, Rizwan HM, Malik MA, et al. Effect of trace element supplementation on the gastrointestinal parasites of grazing sheep of Multan district, Pakistan. J Anim Plant Sci 2020; 30(1): 72-80.

Akhter N, Arijo AG, Phulan MS, lqbal Z. In vivo and in vitro studies on the efficacy of anthelmintics against Haemonchus contortus in goats. Pak Vet J 2014; 34(3): 329-332.

Alawa CBI, Adamu AM, Gefu JO, Ajanusi OJ, Abdu PA, Chiezey NP, et al. In vitro screening of two Nigerian medicinal plants (Vernonia amygdalina and Annona senegalensis) for anthelmintic activity. Vet Parasito/ 2003; 113(1): 73-81. http://dx.doi.org/10.1016/S03044017(03)00040-2. PMid:12651218.

Al-Snafi AE. Medicinal plants affected contractility of smooth muscles- a review. IOSRJ Pharm 2018; 8(11): 22-35.

Al-Snafi AE. The constituents and biological effects of Arundo donax- a review. Int J Phytopharm Res 2015; 6(1): 34-40.

Altemimi A, Lakhssassi N, Baharlouei A, Watson DG, Lightfoot DA. Phytochemicals: extraction, isolation, and identification of bioactive compounds from plant extracts. Plants 2017; 6(4): 42. http://dx.doi.org/10.3390/plants6040042. PMid:28937585.

Amalraj A, Gopi S. Biological activities and medicinal properties of Asa foetida: a review. J Tradit Complement Med 2016; 7(3): 347-359. http://dx.doi.org/10.1016/j.jtcme.2016.11.004. PMid:28725631.

Amudhan MS, Begum VH, Hebbar KB. A review on phytochemical and pharmacological potential of Areca catechu L. seed. Int J Pharm Sci Res 2012; 3: 4151-4157.

Atma W, Larouci M, Meddah B, Benabdeli K, Sonnet P. Evaluation of the phytoremediation potential of Arundo donax L. for nickelcontaminated soil. Int J Phytoremediation 2017; 19(4): 377-386. http://dx.doi.org/10.1080/15226514.2016.1225291. PMid:27592714.

Baby AA, Raphael RG. Potential antimicrobial, anthelmintic and antioxidant properties of Areca catechu L. root. Int J Pharm Pharm Sci 2014; 6(6): 486-489.

Badar N, Iqbal Z, Sajid MS, Rizwan HM, Jabbar A, Babar W, et al. Documentation of ethnoveterinary practices in district Jhang, Pakistan. J Anim Plant Sci 2017; 27(2): 398-406.

Bate-Smith EC. The phenolic constituents of plants and their taxonomic significance. I. Dicotyledons. BotJ Linn Soc 1962; 58(371): 95-103. http://dx.doi.org/10.1111/j.1095-8339.1962.tb00890.x.

Bizimenyera ES, Githiori JB, Eloff JN, Swan GE. In vitro activity of Peltophorum africanum Sond. (Fabaceae) extracts on the egg hatching and larval development of the parasitic nematode Trichostrongylus colubriformis. Vet Parasitol 2006; 142(3-4): 336-343. http://dx.doi.org/10.1016/j.vetpar.2006.06.013. PMid:16899339.

Butter NL, Dawson JM, Wakelin D, Buttery PJ. Effect of dietary tannin and protein concentration on nematode infection (Trichostrongylus colubriformis) in lambs. J Agric Sci 2000; 134(1): 89-99. http://dx.doi.org/10.1017/S0021859699007315.

Chopra RN, Nayyar SL, Chopra IC. Glossary of Indian medicinal plants. New Delhi, India: Council of Scientific and Industrial Research; 1956.

Chu NS. Effects of betel chewing on the central and autonomic nervous systems. J Biomed Sci 2001; 8(3): 229-236. http://dx.doi. org/10.1007/BF02256596. PMid:11385294.

Coles GC, Bauer C, Borgsteede FH, Geerts S, Klei TR, Taylor MA, et al. World Association for the Advancement of Veterinary Parasitology (W.A.A.V.P) methods for the detection of anthelmintic resistance in nematodes of veterinary importance. Vet Parasitol 1992; 44(1-2): 35-44. http://dx.doi.org/10.1016/0304-4017(92)90141-U. PMid:1441190.

Confessor MVA, Mendonça LET, Mourão JS, Alves RRN. Animals to heal animals: ethnoveterinary practices in semi-arid region, Northeastern Brazil. J Ethnobiol Ethnomed 2009; 5(1): 37. http://dx.doi.org/10.1186/1746-4269-5-37. PMid:19941663.

Dhanraj KM, Veerakumari L. Effect of ethanol extract of Areca catechu on fumarate reductase and succinate dehydrogenase of Cotylophoron cotylophorum. Int J Res Develop Pharm Development Life Sci 2016;5(3): 2117-2123.

Duke JA. Handbook of phytochemical constituents of GRAS herbs and other economic plants. London, UK: CRC Press; 1992. 
Faruque MO, Uddin SB, Barlow JW, Hu S, Dong S, Cai Q, et al. Quantitative ethnobotany of medicinal plants used by indigenous communities in the Bandarban district of Bangladesh. Front Pharmaco/ 2018; 9: 40. http://dx.doi.org/10.3389/fphar.2018.00040. PMid:29467652.

Fernch D. Ethnobothany of the Umbelliferae. In: Heywood VH. The chemistry and biology of the umberifella. London, UK: Academic Press; 1971. p. 285-412.

Gasbarre CL, Stout LW, Leighton AE. Gastrointestinal nematodes of cattle in the northeastern US: results of a producer survey. Vet Parasito/ 2001; 101(1): 29-44. http://dx.doi.org/10.1016/S0304-4017(01)00496-4. PMid:11587831.

Ghosal S, Dutta SK, Sanyal AK, Bhattacharya SK. Arundo donax L. (Grarninae): phytochemical and pharmacological evaluation. J Med Chem 1969; 12(3): 480-483. http://dx.doi.org/10.1021/jm00303a032. PMid:5815188.

Goraya K, Iqbal Z, Sajid MS, Muhammad G, Ain QU, Saleem M. Diversity of flora used for the cure of equine diseases in selected periurban areas of Punjab, Pakistan. J Ethnobiol Ethnomed 2013; 9(1): 70. http://dx.doi.org/10.1186/1746-4269-9-70. PMid:24283263.

Gundamaraju R. Evaluation of anti-helmintic activity of Ferula foetida "Hing- A natural Indian spice" aqueous extract. Asian Pac J Trop Dis 2013; 3(3): 189-191. http://dx.doi.org/10.1016/S2222-1808(13)60038-9.

Hofer O, Widhalm M, Greger H. Circular dichroism of sesquiterpene-umbelliferone ethers and structure elucidation of a new derivative isolated from the gum resin 'Asa Foetida'. Monatsh Chem 1984; 115(10): 1207-1218. http://dx.doi.org/10.1007/ BF00809352.

Huang KC. Anthelmintics. In: The Pharmacology of Chinese Herbs. Boca Raton, Florida, USA: CRC press; 1992. p. $321-333$.

Hubert J, Kerboeuf D. A microlarval development assay for the detection of anthelmintic resistance in sheep nematodes. Vet Rec 1992; 130(20): 442-446. http://dx.doi.org/10.1136/vr.130.20.442. PMid:1621342.

Hussain A, Khan MN, Iqbal Z, Sajid MS. An account of the botanical anthelmintics used in traditional veterinary practices in Sahiwal district of Punjab, Pakistan.J Ethnopharmaco/ 2008; 119(1): 185-190. http://dx.doi.org/10.1016/j.jep.2008.06.034. PMid:18657602.

Iqbal Z, Lateef M, Ashraf M, Jabbar A. Anthelmintic activity of Artemisia brevifolia in sheep. J Ethnopharmacol 2004; 93(2-3): 265268. http://dx.doi.org/10.1016/j.jep.2004.03.046. PMid:15234763.

Iqbal Z, Sarwar M, Jabbar A, Ahmed S, Nisa M, Sajid MS, et al. Direct and indirect anthelmintic effects of condensed tannins in sheep. Vet Parasito/ 2007; 144(1-2): 125-131. http://dx.doi.org/10.1016/j.vetpar.2006.09.035. PMid:17097807.

Jabbar A, Iqbal Z, Kerboeuf D, Muhammad G, Khan MN, Afaq M. Anthelmintic resistance: the state of play revisited. Life Sci 2006; 79(26): 2413-2431. http://dx.doi.org/10.1016/j.Ifs.2006.08.010. PMid:16979192.

Kajimoto T, Yahiro K, Nohara T. Sesquiterpenoid and disulphide derivatives from Ferula assa-foetida. Phytochemistry 1989; 28(6): 1761-1763. http://dx.doi.org/10.1016/S0031-9422(00)97841-5.

Kaminsky R, Ducray P, Jung M, Clover R, Rufener L, Bouvier J, et al. A new class of anthelmintics effective against drug-resistant nematodes. Nature 2008; 452(7184): 176-180. http://dx.doi.org/10.1038/nature06722. PMid:18337814.

Kapoor LD. Areca catechu Linn. Handbook of Ayurvedic Medicinal Plants. Boca Raton, Florida, USA: CRC Press; 1990.

Kareparamban JA, Nikam PH, Jadhav AP, Kadam VJ. Ferula foetida "Hing": a review. Res J Pharm Biol Chem Sci 2012; 3(2): 775-786.

Ketzis JK, Taylor A, Bowman DD, Brown DL, Warnick LD, Erb HN. Chenopodium ambrosioides and its essential oil as treatments for Haemonchus contortus and mixed adult-nematode infections in goats. Small Rumin Res 2002; 44(3): 193-200. http://dx.doi. org/10.1016/S0921-4488(02)00047-0.

Khan MN, Sajid MS, Rizwan HM, Qudoos A, Abbas RZ, Riaz M, et al. Comparative efficacy of six anthelmintic treatments against natural infection of Fasciola species in sheep. Pak Vet J 2017; 37(1): 65-68.

Kumar P, Singh DK. In vitro anthelmintic activity of Allium sativum, Ferula asafoetida, Syzygium aromaticum and their active components against Fasciola gigantica. J Biol Earth Sci 2014; 4(1): 57-65.

Kumarasingha R, Preston S, Yeo TC, Lim DSL, Tu CL, Palombo EA, et al. Anthelmintic activity of selected ethno-medicinal plant extracts on parasitic stages of Haemonchus contortus. Parasit Vectors 2016; 9(1): 187. http://dx.doi.org/10.1186/s13071-016-14589. PMid:27036205.

Lateef M, Iqbal Z, Khan MN, Akhtar MS, Jabbar A. Anthelmintic activity of Adhatoda vesica roots. Int J Agric Biol 2003; 5(1): 86-90.

Mali RG, Wadekar RR. In vitro anthelmintic activity of Baliospermum montanum Muell. Arg roots. Indian J Pharm Sci 2008; 70(1): 131-133. http://dx.doi.org/10.4103/0250-474X.40352. PMid:20390101.

McGaw LJ, Van der Merwe D, Eloff JN. In vitro anthelmintic, antibacterial and cytotoxic effects of extracts from plants used in South African ethnoveterinary medicine. Vet J 2007; 173(2): 366-372. http://dx.doi.org/10.1016/j.tvjl.2005.09.004. PMid:16239113.

Miles DH, Tunsuwan K, Chittawong V, Kokpol U, Choudhary MI, Clardy J. Boll weevil antifeedants from Arundo donax. Phytochemistry 1993; 34(5): 1277-1279. http://dx.doi.org/10.1016/0031-9422(91)80015-S. 
Molan AL, Waghorn GC, Min BR, McNabb WC. The effect of condensed tannins from seven herbages on Trichostrongylus colubriformis larval migration in vitro. Folia Parasitol (Praha) 2000; 47(1): 39-44. http://dx.doi.org/10.14411/fp.2000.007. PMid:10833014.

Muhammad G, Khan MZ, Hussain MH, Iqbal Z, Iqbal M, Athar M. Ethnoveterinary practices of owners of pneumatic-cart pulling camels in Faisalabad (Pakistan). J Ethnopharmacol 2005; 97(2): 241-246. http://dx.doi.org/10.1016/j.jep.2004.11.008. PMid:15707760.

Mwale M, Bhebhe E, Chimonyo M, Halimani TE. Use of herbal plants in poultry health management in the Mushagashe smallscale commercial farming area in Zimbabwe. Int J Appl Res Vet Med 2005; 3(2): 163-170.

Nackley LL, Kim SH. A salt on the bioenergy and biological invasions debate: salinity tolerance of the invasive biomass feedstock Arundo donax. Glob Change Biol Bioenergy 2015; 7(4): 752-762. http://dx.doi.org/10.1111/gcbb.12184.

Naumann HD, Tedeschi LO, Zeller WE, Huntley NF. The role of condensed tannins in ruminant animal production: advances, limitations and future directions. Rev Bras Zootec 2017; 46(12): 929-949. http://dx.doi.org/10.1590/s1806-92902017001200009.

Passalacqua NG, Guarrera PM, De Fine G. Contribution to the knowledge of the folk plant medicine in Calabria region (Southern Italy). Fitoterapia 2007; 78(1): 52-68. http://dx.doi.org/10.1016/j.fitote.2006.07.005. PMid:17084993.

Pedreira J, Paz-Silva A, Sanchez-Andrade R, Suárez JL, Arias M, Lomba C, et al. Prevalence of gastrointestinal parasites in sheep and parasite-control practices in NW Spain. Prev Vet Med 2006; 75(1-2): 56-62. http://dx.doi.org/10.1016/j.prevetmed.2006.01.011. PMid:16488032.

Prastowo J, Herawati O, Ariyadi B, Kurniasih. Effects of Areca catechu seed and Anredera cordifolia leaf on Ascaridia galli infection in the domestic chicken (Gallus gallus domesticus). Int J Poult Sci 2017; 16(12): 494-499. http://dx.doi.org/10.3923/ijps.2017.494.499.

Qudoos A, Khan MN, Sajid MS, Muhammad G. Correlation of trace mineral profiles with gastrointestinal worm burden in rangeland sheep of Chakwal District, Punjab, Pakistan. Int J Agric Biol 2017; 19(01): 140-144. http://dx.doi.org/10.17957/IJAB/15.0255.

Radostits OM, Gay CC, Blood DC, Hinchcliff KW. Veterinary Medicine: a Textbook of the Diseases of Cattle, Sheep, Pigs, Goats and Horses. 9th ed. London, UK; W.B. Saunders Company Ltd:; 2000.

Raghavan V, Baruah HK. Arecanut: India's popular masticatory - history, chemistry and utilization. Econ Bot 1958; 12(4): $315-345$. http://dx.doi.org/10.1007/BF02860022.

Rizwan HM, Sajid MS, Iqbal Z, Saqib M. Association of phytomineral with gastrointestinal parasites of grazing sheep in Sialkot district, Punjab, Pakistan. PakJ Agric Sci 2019; 56(2): 459-468.

Rizwan HM, Sajid MS, Iqbal Z, Saqib M. Point prevalence of gastrointestinal parasites of domestic sheep (Ovis aries) in district Sialkot, Punjab, Pakistan. J Anim Plant Sci 2017; 27(3): 803-808.

Sharatkumar S, Dhanachand C, Mohilal N. Study on the efficacy of certain medicinal plants on gastrointestinal helminths of cattle. Indian Vet J 2004; 81(5): 497-498.

Statistical Institute - SAS. Statistical analysis system: user's guide. North Carolina, USA: Statistical Institute; 1998.

Tabassam SM, Iqbal Z, Jabbar A, Sindhu ZD, Chattha Al. Efficacy of crude neem seed kernel extracts against natural infestation of Sarcoptes scabiei var. ovis. J Ethnopharmaco/ 2008; 115(2): 284-287. http://dx.doi.org/10.1016/j.jep.2007.10.003. PMid:18023309.

Thornton PK, van de Steeg J, Notenbaert A, Herrero M. The impacts of climate change on livestock and livestock systems in developing countries: a review of what we know and what we need to know. Agric Syst 2009; 101(3): 113-127. http://dx.doi. org/10.1016/j.agsy.2009.05.002.

Waller PJ, Bernes G, Thamsborg SM, Sukura A, Richter SH, Ingebrigtsen K, et al. Plants as de-worming agents of livestock in the Nordic countries: historical perspective, popular beliefs and prospects for the future. Acta Vet Scand 2001; 42(1): 31-44. http:// dx.doi.org/10.1186/1751-0147-42-31. PMid:11455900.

Wang CK, Lee WH, Peng CH. Contents of phenolics and alkaloids in Areca catechu Linn. during maturation. J Agric Food Chem 1997; 45(4): 1185-1188. http://dx.doi.org/10.1021/jf960547q.

Williamson EM, Okpako DT, Evans FJ. Preparation of plant material. Pharmacological methods in phytotherapy research. Chichester, UK: John Wiley \& Sons; 1998.

Yamson EC, Tubalinal GASP, Viloria VV, Mingala CN. Anthelmintic effect of betel nut (Areca catechu) and neem (Azadirachta indica) extract against liver fluke (Fasciola spp.). J Adv Vet Anim Res 2019; 6(1): 44-49. http://dx.doi.org/10.5455/javar.2019.e310. PMid:31453169.

Zaman MA, Iqbal Z, Khan MN, Muhammad G. Anthelmintic activity of a herbal formulation against gastrointestinal nematodes of sheep. Pak Vet J 2012; 32(1): 117-121.

Zvinorova PI, Halimani TE, Muchadeyi FC, Matika O, Riggio V, Dzama K. Prevalence and risk factors of gastrointestinal parasitic infections in goats in low-input low-output farming systems in Zimbabwe. Small Rumin Res 2016; 143: 75-83. http://dx.doi. org/10.1016/j.smallrumres.2016.09.005. PMid:27766016. 